\title{
Metody geofizyczne w procesie poszukiwania ukrytych zwłok
}

\author{
JACEK ADAMIEC \\ ORCID: 0000-0003-4073-3818 \\ Biegły sądowy przy Sądzie Okręgowym w Warszawie \\ KATARZYNA ZDEB \\ ORCID: 0000-0002-4753-9295 \\ Instytut Archeologii \\ Uniwersytetu Kardynała Stefana Wyszyńskiego w Warszawie
}

\section{Wprowadzenie}

Prowadzenie poszukiwań zwłok i szczątków ludzkich odbywa się na wielu poziomach $\mathrm{i}$ jest prowadzone przez różnorodne grupy specjalistów w ramach badań z zakresu archeologii sądowej i kryminalistyki ${ }^{1}$. Poszukiwanie miejsca zdarzenia powinno rozpocząć się od analizy informacji procesowych udostępnionych przez organy prowadzące postępowanie. W pierwszej kolejności należy przeanalizować akta sprawy, zeznania świadków, dokumenty pisemne, mapy, plany i zdjęcia lotnicze ${ }^{2}$. Przeprowadzenie tego rodzaju kwerend może pomóc wytypować obszar do kolejnego etapu badań.

1 Por. A. Górecki, Metody wykorzystywane przez polskich kryminalistyków i archeologów przy eksploracji mogit — różnice i zbieżności, „Acta Universitatis Lodziensis. Folia Archaeologica" 32, 2017, s. 33; M. Trzciński, Archeologia sądowa w teorii i praktyce, Warszawa 2013; A. Godzień, Archeologia sądowa. Zarys problematyki, Rzeszów 2017.

2 A. Godzień, op. cit., s. 27-29. 
Następnym krokiem poszukiwań powinno być zaplanowanie i przeprowadzenie badań terenowych. Możliwe jest prowadzenie prac niedestrukcyjnych bez ingerowania w badany grunt. Do prowadzenia poszukiwań wykorzystywane są metody geofizyczne oraz badania powierzchniowe. Nierzadko organizowane są w tym celu prospekcje z powietrza przy użyciu np. bezzałogowych statków powietrznych (dronów) ${ }^{3}$, które umożliwiają prowadzenie obserwacji wegetacji roślin (z jednej strony tej osłabionej, a z drugiej — wzmożonej w porównaniu do okolicznego krajobrazu $)^{4}$. Niektóre spośród wymienionych metod mają ponadto możliwość rejestracji danych terenowych podczas prac prowadzonych na obiektach wodnych.

W poniższym artykule zostaną przedstawione wybrane metody geofizyczne, które umożliwiają w znacznym stopniu zawężenie obszaru domniemanego miejsca zdarzenia. Ich zaletą są nieniszczące możliwości analizowania struktur badanego ośrodka oraz otrzymywanie wstępnych wyników już w terenie. Wybrane metody geofizyczne zostaną porównane i omówione w celu przedstawienia ich zastosowania w kryminalistyce i archeologii sądowej. Jednocześnie należy pamiętać, że stanowią one wstęp do prac inwazyjnych, np. odwiertów lub sondaży archeologicznych.

\section{Badania geofizyczne w kryminalistyce}

Badania geofizyczne można podzielić ze względu na rodzaj prowadzonych prac. Pasywne metody związane są z obserwacją i analizą zakłóceń znajdujących się w badanym ośrodku - polegają one na pomiarze anomalii ziemskiego pola magnetycznego, które powstają na skutek ferromagnetycznego oddziaływania niektórych przedmiotów znajdujących się pod powierzchnią. Natomiast aktywne metody związane są z koniecznością wprowadzenia impulsu w ośrodek oraz obserwowaniem sposobu jego rozchodzenia się ${ }^{5}$. Należy podkreślić, iż prace geofizyczne stanowią niezwykle istotny element poszukiwań zwłok i szczątków ludzkich, ponieważ umożliwiają analizę tego, co znajduje się pod powierzchnią, np. gruntu. Pozwalają na wykrycie obiektów, które nie są możliwe do zaobserwowania w krajobrazie.

\footnotetext{
3 M. Trzciński, op. cit., s. 118-126.

4 A. Godzień, op. cit., s. 26.

5 Ibidem., s. 30.
} 
Prace te powinny zostać zaplanowane po zakończeniu kwerendy, ponieważ istotne $\mathrm{w}$ ich prowadzeniu jest wytypowanie oraz zawężenie obszaru badań. Wymagają one odpowiedniego zaplanowania poprzez wytyczenie poligonów badawczych, aby możliwe było ich odpowiednie domierzenie oraz ze względu na konieczność wykonania późniejszych map terenów i udokumentowania przebiegu prac. Niezwykle ważny jest dobór odpowiedniej metody do warunków terenowych. Większość metod można zastosować w bardzo zróżnicowanych warunkach terenowych, ale należy pamiętać o ograniczeniach tychże metod. Zastosowanie metod geofizycznych pozwala na prowadzenie prospekcji w bardzo zróżnicowanych warunkach atmosferycznych, tj. zarówno w wysokich, jak i niskich temperaturach. Ponadto pomiary mogą być dostosowane do niejednolitych rodzajów środowiska - badanego ośrodka. Badania te mogą mieć miejsce na otwartej przestrzeni, na terenie zalesionym lub na obszarze kopalni. Warto podkreślić, że np. przy zastosowaniu metod georadarowej i magnetycznej można prowadzić prospekcję akwenów (i1. 1). Kolejną zaletą badań geofizycznych jest możliwość uzyskania wstępnych wyników już w trakcie trwania prac terenowych. Dlatego też poniżej zostaną przedstawione trzy wybrane metody: magnetometria, badania georadarowe oraz detekcja elementów metalowych, które umożliwiają przeprowadzenie wstępnej analizy wyników podczas prowadzenia badań6.

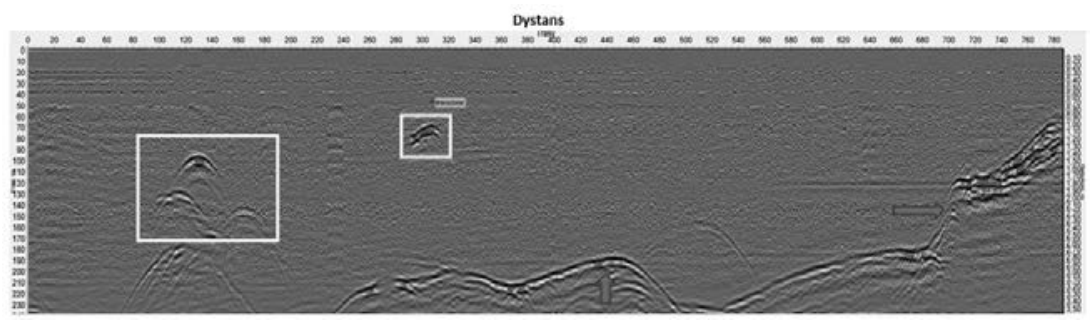

Il. 1. Echogram z badań przeprowadzonych na jeziorze (kolorem białym zaznaczono anomalie, a strzałką zarys brzegu i dna)

Źródło: archiwum firmy GPR24.com.pl Jacek Adamiec.

6 Por. M. Trzciński, Współczesne metody poszukiwań ukrytych zwłok, „Acta Universitatis Lodziensis. Folia Iuridica" 83, 2018, s. 12-14.

Nowa Kodyfikacja Prawa Karnego 56, 2020

(C) for this edition by CNS 


\section{Magnetometria}

Prospekcja magnetyczna umożliwia badanie natężenia pola magnetycznego Ziemi oraz rejestrowanie anomalii będących jego odchyleniem. Anomalie te są wywoływane przez niektóre przedmioty zalegające w badanym ośrodku. $\mathrm{W}$ tych badaniach stosowane są różnorodne magnetometry oraz kapametry. Pozwalają one na wykrycie obiektów, które mają cechy ferromagnetyczne. Przy jej pomocy możliwe jest określenie obecności przedmiotów wykonanych np. z żelaza, kobaltu, niklu oraz tych, które poddano obróbce termicznej (ceglany fundament). Magnetometr umożliwia prowadzenie badań także na obszarach wodnych.

Przy zastosowaniu tej metody nie jest możliwe wykrycie przedmiotów wykonanych z metali szlachetnych i kolorowych. Ponadto niesie ona z sobą ograniczenia, które powoduje — paradoksalnie — jej wrażliwość. Dlatego też podczas prowadzenia prac należy minimalizować kontakt z przedmiotami metalowymi znajdującymi się na badanej powierzchni lub przy osobie prowadzącej prospekcję. Przedmioty ferromagnetyczne powinny zostać usunięte z powierzchni przed rozpoczęciem prac, ponieważ mogą prowadzić do zaburzenia wyników ${ }^{7}$.

Pomimo tych ograniczeń prowadzone metodą prospekcji magnetycznej badania umożliwiają wykrycie miejsc, które mogły zostać zasypane gruzem ceglanym, jak w wypadku jam grobowych, które ktoś próbował ukryć. Zastosowanie magnetometru pozwala również na wykrycie miejsc, w których mogły zostać schowane narzędzia zbrodni, np. broń palna. Ponadto zakłócenia w polu magnetycznym można obserwować w trakcie prowadzenia prac terenowych, co umożliwia wstępne oznaczenie miejsc, które należy poddać badaniom inwazyjnym. Należy podkreślić, iż prace należy zaplanować w taki sposób, aby możliwe było odtworzenie tras badawczych i naniesienie wyników na mapy ${ }^{8}$.

7 Por. K. Misiewicz, Geofizyka archeologiczna, Warszawa 2006, s. 86-98.

8 Por. T. Grabowska, Magnetometria stosowana w badaniach środowiska, t. 2, Kraków 2013, s. 126-131. 


\section{Detekcja elementów metalowych}

Kolejną metodą prowadzenia prospekcji powierzchniowej jest jedna z prospekcji elektromagnetycznych. Fale elektromagnetyczne rozchodzą się w badanym ośrodku w sposób zróżnicowany ze względu na różnorodność składu. Prowadzenie badań przy zastosowaniu detektora metalu związane jest z analizą zaburzeń pola elektromagnetycznego, które jest wytwarzane przez urządzenie. Rejestracja zakłóceń pola pozwala na wykrycie przedmiotów nie tylko o właściwościach ferromagnetycznych. Badania możliwe są dzięki zastosowaniu anten nadawczej (cewki) oraz odbiorczej. Polegają na odbieraniu sygnału przez detektor z chwilą, w której do przedmiotu metalowego zbliża się cewka. Dzieje się tak, ponieważ cewka detektora wytwarza pole elektromagnetyczne, które jest emitowane do gruntu. Na skutek tej działalności obiekty metalowe, które znajdą się w zasięgu tego pola, ulegają wzbudzeniu, tworząc własne pole elektromagnetyczne i emitując fale elektromagnetyczne. Fale te zostają przechwycone przez cewkę, która sygnalizuje występowanie emitujących je przedmiotów. Niektóre spośród detektorów mają możliwość zamiany klasycznej cewki na ramę, co zwiększa zasięg głębokościowy pomiaru detekcyjnego, jednakże prowadzi to do utraty możliwości wykrycia pomniejszych przedmiotów ${ }^{9}$.

Stosowanie detektora metalu wiąże się z pewnymi ograniczeniami. Przy zastosowaniu starszych modeli nie jest możliwe określenie, z jakiego rodzaju metalu przedmiot został wykonany, a w wypadku zastosowania ramy podłączonej do detektora oraz połączenia ich z komputerem, na którym widoczny może być zarys przedmiotu - nie zawsze będzie on odzwierciedlał faktycznie odkryty obiekt. Jednocześnie należy zwrócić uwagę na kwestie związane $\mathrm{z}$ bezpieczeństwem, ponieważ prowadzenie poszukiwań przy zastosowaniu detektora metalu może doprowadzić do odkrycia pocisków lub zapalników, których późniejsze odkopanie może stanowić zagrożenie dla badaczy (o ile w pracach nie uczestniczy saper).

Mimo to prowadzenie prac polegających na detekcji elementów metalowych pozwala na wykrycie przedmiotów związanych prawdopo-

9 M. Trzciński, Archeologia sadowa w teorii i praktyce..., s. 141-143. 
dobnie z popełnieniem przestępstwa lub miejsc pochówków, w których mogły znaleźć się metalowe elementy ubioru bądź fragmenty broni.

\section{Metoda georadarowa}

Trzecią metodą, którą można prowadzić prospekcję powierzchniową w postępowaniu kryminalistycznym, jest metoda georadarowa (GPR Ground Penetrating Radar). Prowadzenie badań przy zastosowaniu tej metody możliwe jest dzięki odpowiedniemu urządzeniu, które pozawala na uchwycenie i późniejszą analizę badanego ośrodka. Georadar wyposażony jest $\mathrm{w}$ antenę nadawczą, która generuje impuls elektromagnetyczny wysyłany następnie w celu poznania jego struktury poprzez zarejestrowanie różnic prędkości fali em emitowanych w badanym ośrodku. W wypadku natrafienia na obiekt fala powraca do anteny odbiorczej z informacją o zmianie prędkości. Po przetworzeniu impulsu elektromagnetycznego możliwe jest wychwycenie obecności anomalii w badanym ośrodku. Przebyta trasa mierzona jest przy pomocy koła, które zapisuje przebytą odległość jako długość pojedynczego profilu. Na tym profilu widoczne jest rozchodzenie się fali w badanym ośrodku, a także jej przyspieszenie na wykrytych obiektach (co pozwala na zapisanie ich w formie anomalii) ${ }^{10}$.

Niektóre prace planowane są na niezwykle trudnym terenie, który nierzadko wpływa na otrzymywane wyniki. Anomalie mogą być wywoływane różnego rodzaju obiektami znajdującymi się pod powierzchnią gruntu, np. rurami żeliwnymi i innymi warstwami, które mogą doprowadzić do wytłumienia fali em, co spowoduje spadek jakości zarejestrowanych danych w wypadku mniejszych obiektów.

Badania georadarowe mogą być prowadzone na zróżnicowanym terenie. Metoda ta umożliwia również pracę w celu zawężenia obszaru poszukiwań poprzez typowanie miejsc wyraźnych anomalii w terenie. Jednakże prowadzenie poszukiwań przy zastosowaniu tej metody pozwala na odkrycie zarysów wkopów mogił lub pojedynczych grobów

10 Por. J. Stojer-Polańska, M. Lisowicz, J. Gołębiowski, Kryminalistyczne aspekty poszukiwania zwtok, „Problemy Kryminalistyki” 289, 2015, nr 3, s. 4-5. 
$(\text { il. } 2)^{11}$. Pozwala także na zlokalizowanie miejsc pochówku, które ukryte są w budynkach lub ich pozostałościach ${ }^{12}$.

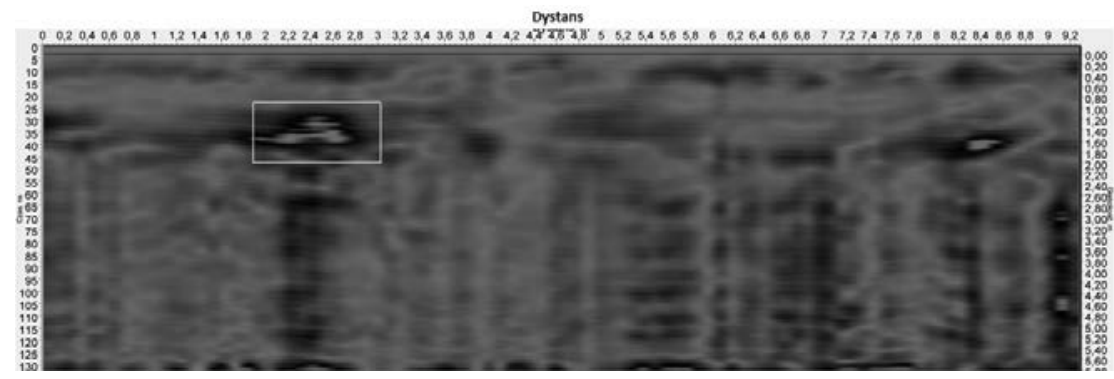

Il. 2. Echogram z poszukiwań (kolorem białym zaznaczono anomalie, a strzałką zarys brzegu i dna)

Źródło: archiwum firmy GPR24.com.pl Jacek Adamiec.

\section{Możliwości zastosowania metod w kryminalistyce}

Poszukiwanie zwłok i szczątków ludzkich w kryminalistyce, jak również archeologii sądowej, może przynieść dobry rezultat przy zastosowaniu badań geofizycznych w prowadzonym postępowaniu. Odpowiedni dobór metody powinien rozpocząc się na etapie analizy innych dostępnych materiałów. Przeprowadzenie odpowiedniej kwerendy umożliwia także przewidzenie potencjalnych zakłóceń i ich wyeliminowanie $\mathrm{w}$ trakcie prac. Znajomość terenu i wcześniejsza prospekcja przygotowawcza prowadzą do zastosowania jak najszerszego spektrum metod geofizycznych ${ }^{13}$. Ponadto rozpoznanie terenowe umożliwia odpowiedni dobór anteny georadarowej o właściwej częstotliwości, jeśli zaistnieje konieczność uzyskania większej rozdzielczości pionowej. W planowaniu

11 Por. E. Mazurek, S. Tomecka-Suchoń, Georadar w stużbie prawa, „Wszechświat" 114, 2013, nr 4-6, s. 112-114.

12 Por. M. Zubańska, P. Knut, Niewykryte przestępstwa sprzed lat, nowoczesne narzędzia techniki kryminalistycznej i policyjne Zespoly do spraw Przestępstw Niewykrytych, czyli crimen grave non potest esse impunibile, „Problemy Kryminalistyki” 299, 2018, nr 1, s. 18-19.

13 Por. J. Stojer-Polańska, M. Lisowicz, J. Gołębiowski, op. cit., s. 8-9. 
badań równie istotne jest doświadczenie i przygotowanie osób prowadzących poszukiwania oraz zespołu badawczego.

Zaplanowanie prac ma również znaczenie ze względu na prowadzenie prac geodezyjnych. Wytyczenie poligonów i podanie ich wymiarów umożliwia w późniejszym czasie umieszczenie otrzymanych wyników z informacją o wykrytych anomaliach na mapach badanych obszarów.

Należy podkreślić, że prowadzenie uważnej obserwacji w trakcie prac terenowych, a także oznaczanie anomalii na miejscu prac oraz wprowadzanie znaczników (markerów) na echogramach ułatwia analizę zebranych danych i ich dalsze opracowanie.

W zależności od rodzaju prowadzonych prac i czasu, jaki można poświęcić na interpretację zebranych odczytów, możliwe jest rozpoczęcie wstępnej analizy wyników już w terenie. Oznaczenie anomalii pozwala na przeprowadzenie od razu wstępnej weryfikacji, np. poprzez wykonanie odwiertów. Niektóre zaobserwowane zakłócenia widoczne w badanym ośrodku mogą nie być widoczne na echogramach, a wyniki otrzymane w 2D mogą nie być pełne. Dlatego też w miarę możliwości należy pamiętać o odpowiednim ich opracowaniu, co pozwala na otrzymanie obrazowania w 3D. Umożliwia ono ustalenie, czy odczyty niektórych obiektów nie zostały zaburzone (stłumione) przez inne, które zalegały nad nimi. Takie opracowanie daje szansę na prowadzenie obserwacji na różnych poziomach głębokości badanego ośrodka ${ }^{14}$.

W wypadku planowania i prowadzenia badań geofizycznych należy pamiętać, że głównym celem jest zawężenie pierwotnego obszaru prospekcji. Trzy powyżej opisane metody umożliwiają prowadzenie obserwacji w trakcie ich trwania. Pozwalają one na wytypowanie miejsc anomalii, które następnie należy poddać weryfikacji inwazyjnej, aby określić, z jakim rodzajem obiektu mamy do czynienia. Interpretacja otrzymanych wyników powinna być niezwykle ostrożna, a sama prospekcja prowadzona w miarę możliwości za pomocą przynajmniej dwóch metod niedestrukcyjnych. Jeżeli nie jest to możliwe, należy pamiętać o możliwościach i ograniczeniach każdej z metod.

Wszystkie powyżej przedstawione metody umożliwiają prowadzenie prac poszukiwawczych, których celem jest odnalezienie miejsca, gdzie znajdują się zwłoki lub szczątki ludzkie. Różnorodność metod

14 Por. A. Godzień, op. cit., s. 29. 
geofizycznych umożliwia ich prowadzenie w bardzo zróżnicowanych warunkach terenowych i atmosferycznych. Pozwala to na wytypowanie obszaru prac archeologicznych — sondaży albo konkretnych miejsc, w których należy wykonać odwierty, będące etapem weryfikacyjnym dla otrzymanych wyników.

Prowadzenie badań geofizycznych umożliwia wznawianie śledztw nie tylko w ramach działalności Archiwum X, ale również na użytek współcześnie trwających postępowań prokuratorskich lub sądowych. Prowadzenie badań z zastosowaniem wyżej wymienionych metod pozwala weryfikować informacje uzyskane na podstawie dostępnych dokumentów oraz analizy map i zdjęć lotniczych. Badania te powinny stanowić ważny etap weryfikacji zeznan świadków i przeszukania domniemanych miejsc zdarzeń. Zastosowanie metod geofizycznych — jednej wybranej lub kilku, aby otrzymać weryfikację wyników — przyczynia się również do rozwoju wiedzy historycznej, także w wypadkach pochówków wojennych czy ofiar zbrodni przeciwko pokojowi, ludzkości oraz zbrodni wojennych. Prace te mogą być wykonywane w ramach projektów zarówno z zakresu archeologii sądowej, jak i kryminalistyki ${ }^{15}$.

\section{Bibliografia}

Godzień A., Archeologia sądowa. Zarys problematyki, Rzeszów 2017.

Górecki A., Metody wykorzystywane przez polskich kryminalistyków i archeologów przy eksploracji mogił — różnice i zbieżności, ,Acta Universitatis Lodziensis. Folia Archaeologica" 32, 2017, s. 23-46.

Grabowska T., Magnetometria stosowana w badaniach środowiska, t. 2, Kraków 2013.

Mazurek E., Tomecka-Suchoń S., Georadar w służbie prawa, „Wszechświat” 114, 2013, nr 4-6, s. 112-114.

Misiewicz K., Geofizyka archeologiczna, Warszawa 2006.

Stojer-Polańska J., Lisowicz M., Gołębiowski J., Kryminalistyczne aspekty poszukiwania zwłok, „Problemy Kryminalistyki” 289, 2015, nr 3, s. 3-10.

Trzciński M., Archeologia sądowa w teorii i praktyce, Warszawa 2013.

Trzciński M., Praktyczne problemy realizacji badań archeologicznych $w$ zwiąku z prowadzeniem poszukiwań ofiar zbrodni komunistycznych, „Kurier Konserwatorski” 2017, s. 7-14.

15 Por. M. Trzciński, Praktyczne problemy realizacji badań archeologicznych w związu z prowadzeniem poszukiwań ofiar zbrodni komunistycznych, „Kurier Konserwatorski” 2017, s. 7-16.

Nowa Kodyfikacja Prawa Karnego 56, 2020

(C) for this edition by CNS 
Trzciński M., Wspótczesne metody poszukiwań ukrytych zwłok, „Acta Universitatis Lodziensis. Folia Iuridica" 83, 2018, s. 7-20.

Zubańska M., Knut P., Niewykryte przestępstwa sprzed lat, nowoczesne narzędzia techniki kryminalistycznej i policyjne Zespoty do spraw Przestępstw Niewykrytych, czyli crimen grave non potest esse impunibile, „Problemy Kryminalistyki” 299, 2018, nr 1, s. 14-24.

\title{
Geophysical methods in the process of searching for hidden corpses
}

\begin{abstract}
Summary
In this article, the author presents how to use geophysical research to look for corpses. During the search, the following methods can be used: GPR, magnetic and metal detector, which assists in the detection of graves and mass graves. Research can be conducted as part of forensic archaeology and prosecutor's proceedings. This article presents the possibilities and limitations of these methods.
\end{abstract}

Keywords: GPR, magnetic, metal detector, forensic archaeology. 